\title{
Mutual Interdependence between Elites and the Poor
}

\author{
Chipiliro Kalebe-Nyamongo*
}

November 2010

\begin{abstract}
There has been a growing recognition among scholars that politics matters in the distribution of resources in society. However, attempts to use a political economy 'lens' with which to explore causes of poverty and strategies for poverty alleviation have largely ignored elites. By failing to embrace the crucial role elites play in the implementation of pro-poor policy, existing research has not produced a holistic understanding of the underlying factors which inhibit or promote action towards propoor policy. Historical accounts of the evolution of welfare states in the UK and USA inform us that elites prioritization of poverty reduction is driven by the extent to which elites and the poor are interdependent, such that the presence of the poor has a positive or negative impact on elite welfare. Drawing on research into elite views of poverty and the poor in Malawi, this paper argues that in formulating effective, responsive, and comprehensive strategies for poverty reduction, the role of elites must be considered in addition to the adoption of democratic, economic, and social institutions.
\end{abstract}

Keywords: Malawi, elites, politics of poverty, pro-poor policy

JEL classification: O2, O17, O38, O55

Copyright (C) UNU-WIDER 2010

* University of Birmingham, UK. E-mail: cfk487@bham.ac.uk

This study has been prepared within the UNU-WIDER project on The Role of Elites in Economic Development, directed by Alice Amsden, James Robinson, and Alisa DiCaprio.

UNU-WIDER gratefully acknowledges the financial contributions to the research programme by the governments of Denmark (Royal Ministry of Foreign Affairs), Finland (Ministry for Foreign Affairs), Sweden (Swedish International Development Cooperation Agency-Sida) and the United Kingdom (Department for International Development-DFID). 
The World Institute for Development Economics Research (WIDER) was established by the United Nations University (UNU) as its first research and training centre and started work in Helsinki, Finland in 1985. The Institute undertakes applied research and policy analysis on structural changes affecting the developing and transitional economies, provides a forum for the advocacy of policies leading to robust, equitable and environmentally sustainable growth, and promotes capacity strengthening and training in the field of economic and social policy making. Work is carried out by staff researchers and visiting scholars in Helsinki and through networks of collaborating scholars and institutions around the world.

www.wider.unu.edu publications@wider.unu.edu

UNU World Institute for Development Economics Research (UNU-WIDER)

Katajanokanlaituri 6 B, 00160 Helsinki, Finland

Typescript prepared by Janis Vehmaan-Kreula at UNU-WIDER

The views expressed in this publication are those of the author(s). Publication does not imply endorsement by the Institute or the United Nations University, nor by the programme/project sponsors, of any of the views expressed. 


\section{Introduction}

In the dispute between the advocates of structure and agency, structural explanations have dominated explanations of socioeconomic and political behaviour towards poverty and determined the solutions that would improve on this problem. In order to promote economic growth, accountability, responsiveness, and transparency, developing countries have been encouraged to adopt institutions and social policies that are supposed to lead to poverty reduction. Developing countries have formulated strategies such as Poverty Reduction Strategy Papers (PRSP) and pro-poor budgets that prioritize the Millennium Development Goals (MDGs) as well as emphasize empowerment, participation by citizens and good governance. Analyses of these strategies reveal the anti-political nature taken in finding solutions to the poverty problem. While a lot has been written about the ways the poor perceive their situation (Narayan et al. 2000a, 2000b, 2002), very little is known about the perceptions of poverty held by elites, particularly in developing countries, and then how these perceptions impact pro-poor policy.

In studying the causes of poverty, researchers have established correlates between poverty and factors such as assets, education, occupation, ethnicity, and geography. But they have failed to explain how and why these factors have these effects on poverty and have ignored the processes of accumulation, economic distribution, and political power. In solving Africa's problems, the politics, the power of elites, and the distribution of resources have been ignored. If politics has entered into poverty discourses, it has been in terms of its destructive nature and elites have been characterized as rational, calculating and Machiavellian individuals (Robinson 2003: 4) bent on blocking propoor policy or using these resources for personal gain (Riddell 1999: 328).

There is consensus within much of the literature on poverty that in nations where absolute poverty persists, powerful actors conspire to prevent the elimination of poverty because they benefit from it (Diamond 2003: 6-7). Other authors add that studying elites disregards and diminishes the importance of the perceptions that poor people have about their own situation (Narayan et al. 1999; World Bank 2000; Witteveen et al. 2008). Nevertheless growing poverty and neopatrimonial regimes in many African countries have demonstrated the influence elites hold over the adoption, adaption, and implementation of institutions and policy prescriptions.

This paper seeks to contribute to the theoretical and empirical understanding of the extent to which elite perceptions of poverty and the poor impact the implementation of poverty reduction initiatives. It aims to improve our understanding of how and why elites support, oppose or ignore the implementation of pro-poor policy. Drawing on both quantitative and qualitative data from Malawi, the paper argues that in formulating effective, responsive, and comprehensive strategies for poverty reduction, the role of

elites is essential. Sustainable poverty reduction is dependent upon an elite that is committed to and has the political will to promote pro-poor policies. Employing De Swaan's (1988: 13-32) theory of social consciousness as its theoretical base, the paper also demonstrates that elites in Malawi are aware of the mutual dependency among social groups in society.

This paper proceeds as follows. The next section provides a historical account of the importance of elites in the implementation of pro-poor policy by drawing on literature on the evolution of welfare policies in nineteenth century UK and USA. This 
literature leads to the main questions of the paper. How do elites talk about the issue of poverty and the poor in Malawi? To what extent do elites feel their welfare is impacted by the presence of poverty? And how does this impact their preferred solutions to poverty? Sections three and four discuss why Malawi offers an interesting case study in understanding the role of elites in the politics of pro-poor policy. It points out that structural/institutional explanations of and solutions to poverty are inadequate in understanding the persistence of poverty in Malawi. Section five analyses the results of the study and finds that although elites perceive their ties with the poor to be strong, their view of the poor as passive, dependant and fatalistic points to their lack of fear of the presence of the poor.

\section{Historical arguments on the role of elites in formulating pro-poor policy}

Elite's classification of the poor in terms of worthiness has powerfully influenced national policies, shifting towards assisting the worthy or deserving poor rather than the undeserving poor. Nineteenth century UK and the USA provide examples of this distinction among the poor leading to the exclusion of the most vulnerable members of society. Elites in these two countries developed ideologies that justified the presence of the poor and held the poor responsible for their position in society.

The images of the poor in the USA reinforced the belief in self-help and the American dream, which interprets poverty as a result of personal failure (Lister 2004). Elites believed that income, wealth and social position depended wholly on hard work, ability, honesty, and responsibility. Similarly, in early nineteenth century UK a distinction was made between the dependent and the independent poor; paupers and the labouring poor; the deserving and the undeserving poor. 'This distinction had obvious moral implication as well as social and political ones' (Himmelfarb 1991: 122). It served to protect the respectable from the morally undesirable and to facilitate a vast machinery of disciplinary social intervention aimed at remoralization (Squires 1990 in Lister 2004) with social support targeted at the deserving poor.

Early theories of the causes of poverty were based on individual and group deficiencies. There was a belief that the exercise of the virtues of diligence, prudence, sobriety, thrift, and initiative was the pathway to affluence. Therefore, poverty was caused by defects of character which the individual could, if they chose, overcome. 'Although hazards of life such as unemployment, sickness, old age, death of the breadwinner was acknowledged, it was the mark of a provident man that he set aside savings to cover these risks' (Berthoud 1981: 7). However, it was later recognized that among those in poverty were decent, hard working, good living, and provident people, who in spite of personal effort were defeated by successive and prolonged crises beyond their control. This led to a categorization of poor people between the deserving, who were poor due to no fault of their own and the undeserving, those whose poverty was due to character defects such as laziness, drunkenness, and immorality.

This categorization of the poor became a way of ranking or prioritizing the poor according to need and had an influence on which policies targeted which category of poor people as well as the way in which resources were allocated (Hossain 2005). Lister (2004) lists three ways in which distinctions were made in categorizing the poor:

(a) Between pauperism and poverty between which dividing line was thin and permeable as individuals slipped across the two. Hence welfare policy attempted to prevent the poor from lapsing into pauperism; 
(b) Between undeserving, able-bodied, and the deserving impotent/incapable paupers, which resulted in relief that was restricted to absolute necessities and provided in a form that deterred the recipients from desiring to remain dependent upon it and deterred others from conduct that would result in destitution (Berthoud 1981);

(c) The third differentiation was aimed at charting and containing the dangerous and criminal class, who invoked fear of criminality, vice, sexual immorality, pollution, and a threat to the social order. Therefore, the poor were to be kept at a distance as they were feared as a source of both physical and moral filth and contamination.

This last point illustrates the realization by elites of the impact the presence of the poor has on elite welfare. Implicit in Lister's (2004) argument is the fact that when people settle in one territory, develop resources and build up stocks, they develop mutual dependencies. Interdependence is best illustrated by nineteenth century Europe where it was realized that the mass outbreak of cholera was a result of the living conditions among the urban poor. The first solution by elites was to move from those areas populated by the urban poor into suburbs, leading to the creation of slums. Elites soon recognized that in order to prevent the spread of diseases beyond the slums and insulate themselves from diseases, they must provide fresh water and sewerage connections to these slums (De Swaan 1988).

In some instances welfare support did not necessarily target the poorest, but the slightly or temporarily poor, further accentuating the preference for the deserving poor. Historical examples include, welfare support towards the members of the upper castes during the 1943 Bengal famine and assistance for the Victorian Londoners threatened with descent into the ranks of the unrespectable (Himmelfarb 1991). Today, this still exists, for example, in Bangladesh, where the sudden downward mobility of a household receives more sympathy and has a strong likelihood of accessing national health programmes (Hossain 2005). Similarly, the political discourse in Ghana reveals a strong bias towards the economically active, leaving the poorest excluded from poverty programmes (Hickey 2005; Hossain 2005). This illustrates that policy, particularly propoor policy, is not always a result of benevolence or altruism, but also self-interest and rarely an expression of pure humanitarian impulse' (Toye 1999).

Research carried out in the UK and USA has underlined the importance these perceptions or images of the poor have had on the development of punitive attitudes and policies towards welfare recipients (Lister 2004). Studies have underscored the important linkages that exist, not only between politics and pro-poor policy, but also between those with power within the policy-making process, their perceptions and outcome of such policies. They show that agency-based explanations that focus on what people in poverty do or do not do are inadequate for dealing with poverty. Rather, there is a need to focus on agency-based explanations that turn our attention towards what powerful people do or do not do and the impact of their actions. 'While the actions of individuals in poverty can be a contributory factor, the underlying causes of poverty are to be found in the wider society. We need to pay more attention to the exercise of agency of poor people, but this cannot be divorced from their severely disadvantaged structural position or from the exercise of agency by more powerful actors, which helps to perpetuate that structural position' (Lister 2004: 178). 


\section{Elites, politics, and policy in Malawi}

Malawi offers an interesting case study for understanding the importance of elites in the politics of pro-poor policy, given its unsuccessful attempts at reducing poverty. Malawi is known for developing good policies targeted at reducing poverty that are rarely implemented successfully. A study of the budget process in Malawi concluded that the budget process is a theatre that masks the real distribution and spending (Rakner et al. 2004). There is no realistic estimate of revenue or spending in the planning, formulation and implementation of the budget. Malawi's transition from an authoritarian one-party state towards a democratic form of government is considered a 'transition without transformation' because many structures, systems, and personalities have remained the same (Cammack 2004). Most importantly, the expected impact democracy would have on poverty reduction has been minimal.

The transition towards democracy in Malawi brought with it expectations for the attainment of various freedoms and also a time when poverty could openly be discussed, examined, and solutions implemented. But since 1994, despite the implementation of various pro-poor policies the level of poverty is still high and inequality even higher. Three years into democratic rule Malawi faced two food crises, fiscal instability, and political intimidation similar to the one-party era resulting in the withdrawal of aid by donors. The rhetoric that democracy will result in development, equitable distribution of resources and good governance is not consistent with the reality in Malawi. This is typical of many African countries; despite political changes and the adoption of better governance institutions, there is little evidence that these changes have resulted in more effective, accountable, and responsive governments (Chabal 2002).

In this section I argue that the adoption of democratic institutions does not alone suggest a change in elite behaviour or in the actions they take. The persistence of poverty reflects its institutionalization within social and political norms as well as institutions and its acceptance within political discourse. Hence, noble agendas - such as empowerment of the poor, or increased political space for the poor to participate in offer very little promise if the elites who are required to adopt and implement these institutions are anyhow ignored. The welfare impact of these institutions is a result of how elites choose to exercise their influence or power. The answer lies in the reallocation of resources and shifting power relations within which poverty is embedded and tolerated. 'The inclusion of the poor in participatory poverty assessments, may have little weight compared to the ways in which poverty and the poor are represented within elite political discourse' (Hickey and Bracking 2005: 854).

Malawi is known for developing good policies for poverty reduction that are rarely implemented successfully. Because key initiatives are often introduced by presidential candidates and other 'big men' on the campaign trail, their viability beyond these political campaigns is limited. Policies adopted are short-term in nature with no technical analysis and input or institutionalized decision-making. Personality politics prevents co-ordination within government, while the tailoring of policies and their implementation in order to maximize opportunities for personal enrichment or to pay off political debts compromises their effectiveness. Unnecessary AIDS deaths and needless starvation have been among the consequences (Booth et al. 2006).

Despite heavily investing in food security by both government and the donor community, Malawi still experiences recurrent food crises. One explanation for Malawi's recurrent food security problems is its failure to become a developmental state. In developmental states political and bureaucratic elites have incentive to promote 
economic growth, in order to catch up or to protect or promote itself as well as win legitimacy by delivering steady improvements in the material and social well-being of its citizens (Cammack 2006: 1). Therefore, understanding elites and the role they play in the politics of pro-poor policy is important.

Three issues in Malawi make understanding elites important as they point to the failure of the political system argument to fully explain the success or failure of pro-poor policy. First, democracy has had minimal impact on poverty and has not empowered the poor. Second, democracy has not resulted in an accountable or responsive government. Instead neopatrimonial practices have continued from the one party to a democratic state. Last, democracy has not changed the nature of Malawi's traditional society. Thus, social relationships are still characterized by inequality and a large power distance. Citizens gladly defer to authority which makes it difficult or impossible for the poor to hold elites to account. This explains why abuses are tolerated even when few benefits trickle down to poor people (Booth et al. 2006).

The structural underpinnings of Malawi's political system of neopatrimonialism have changed little under democracy. Leaders continue to use patronage and clientelism to retain power and legitimacy (Cammack et al. 2007; O’Neil 2007). The only difference was the one-party state led by Kamuzu Banda did not practice a free-for-all patronage. He retained tight control over the allocation of power and wealth. By contrast, the democratic rule of Bakili Muluzi lost control of the patronage system such that it became a free-for-all and led to an increase in corruption at all levels within the civil service. The second democratic president, Bingu Wa Mutharika inherited the leadership styles of both Muluzi and Banda to build personal and political support. Bingu has reached out to civil society, the media, taken a zero-tolerance stand on corruption but at the same time adopted populist policies such as input subsidies and road-building to gain support. He has also used patronage, especially the promise of public office appointments to encourage opposition politicians to join his party (Cammack et al. 2007).

The argument that democracy is better for development than authoritarianism has not been consistent with Malawi’s experience. Democracy in Malawi has had a differential impact on the poor and it is the particular choices that the elites in Malawi have made that have influenced the nation's institutions and development prospects. These leaders have differed in their approach towards policy especially on policy consistency, longterm vision, ability to discipline and coordinate both donors and different arms of government in line with their vision, prioritization of objectives and resources, and the improved performance of the civil service (Booth et al. 2006; Cammack et al. 2007).

The way in which institutions are used or implemented is dependent on the choices of elites. Elites are the missing link in explaining the success or failure of pro-poor policy and understanding their perceptions, ideas,, and attitudes in conjunction with capacity training, good governance, and democratic reforms are essential. Perceptions dictate behaviour, therefore pro-poor policies are a reflection of how elites perceive them; in other words, poverty reduction begins in the minds of elites. Perceptions provide the fabric in which public initiative can be sewn and can become entangled. They shape or constrain leaders' decisions by creating the space for addressing issues, the nature of the approach to deal with them and set of solutions to be considered (Selee 2005). 


\section{Poverty trends and pro-poor policies in Malawi}

According to the Integrated Household Survey (IHS) of 1997/1998 and 2004/2005, there has been very little change in the rate of poverty since 1998. Malawi remains one of the poorest countries in sub-Saharan Africa with 52.4 per cent of the population poor and 22.3 per cent ultra-poor. These figures are according to the World Bank poverty line of those living below US\$1.25 a day. This indicates that one in five people lives in dire poverty such that they cannot even afford to meet the minimum food requirement (NSO 2005). Malawi's per capita income has grown by only 0.2 per cent per annum over the last 30 years despite attempts by successive governments and donors to improve the lives of the poor. In addition to being poor, Malawi faces several challenges, among them the AIDS pandemic, chronic malnutrition, declining soil fertility, shortages of land and inadequate agricultural policies (Conroy 2006; Action Aid 2006).

Poverty in Malawi is a reflection of both economic underdevelopment and the failure of pro-poor policies, either in the ways that resources are distributed or policies are implemented and whether the policies address the real causes of poverty. Hence, poverty in Malawi is experienced through unemployment and through a lack of access to resources or social services such as access to education, health services, food etc. Thus, location is an important indicator of a person's level of poverty. For instance, 60 per cent of the rural population is living in poverty compared to 25 per cent in urban areas. This is mainly because the rural areas are less developed than urban areas in terms of roads, schools, health centres, and business centres. Additionally, agricultural policies implemented in Malawi over the past forty years have increased inequality.

The fact that poverty is more pronounced the rural areas does not negate the fact that urban poverty is also severe. High urbanization since the 1980s (from 8 per cent in 1975 to 25 per cent in 2000) has meant increased population in the urban areas. High urbanization has not been matched by a growth in employment levels, but worsening urban life and increasing slums in Malawi's cities. Urban unemployment has therefore increased as only 30,000-35,000 jobs are created each year for 200,000 job seekers (USAID 2002). Without employment people are unable to pay for services such as health, education, or clean water, and are also vulnerable to inflation. USAID (2002) observes that in urban settings there has been escalating cases of armed robberies in offices, homes, and car thefts. This suggests that there is a link between the level of poverty and social ills in society. The people targeted are usually the better-off of which elites are a part, suggesting a mutual dependency between elites and the poor. This interdependence between the elites and poor becomes central to the collectivizing process that drives policies towards poverty.

In order to grasp the extent to which structural or agential factors explain socioeconomic and political behaviour, it is important to understand the policies that have been implemented in Malawi since attaining independence in 1964 and their impact on poverty. Structural arguments emphasize the impact of the political system prevailing governance institutions and the rule of law. Structural arguments have largely been used to explain socioeconomic and political behaviour and its impact on poverty. Thereby ignoring the role of agency to act and influence policy, particularly the role of elites. However, structures or institutions have different outcomes for the poor and agency accounts for this difference. This leads us to focus more on the role that elites play in the politics of pro-poor policy.

A discussion of how various democratic governments in Malawi have implemented propoor polices reveals factors that have resulted in their success or failure. Factors include 
external shocks; over reliance on agriculture; failure to diversify the economy; geographic location; poor infrastructure; and low educational levels. Other factors include weak governance, corruption, and poor macroeconomic management. These factors point to the importance of decision-making by ruling elites and the choices they make in regards to the nature of pro-poor policies implemented.

Following independence in 1964, Malawi, under the autocratic leadership of Kamuzu Banda, implemented various strategies guided by two major policies: Devpol 1 and Devpol 2. Banda's policies were aimed at attaining economic independence, therefore many social sectors such as health and primary education were sidelined or ignored. Instead, emphasis was put on increasing agricultural productivity, export earnings, and domestic income to ensure the availability of needed skills. Secondary, technical, and university education were prioritized at the expense of primary school education (Pryor 1990). These policies reveal Banda's value orientation which prioritized economic growth over direct welfare support. The official view of the Banda regime was that as long as every Malawian was well fed, lived in a house which did not leak and had adequate clothing, there was no poverty (Chinsinga 2002).

The manner in which Banda implemented his policies also had a damaging impact on the level of poverty and inequality. Policy was dualistic in nature and gave preferential treatment towards the estate sector at the expense of the smallholder sector. The estate sector, which was dominated by elites, grew rapidly. The bias in Banda's policy took several forms: customary land was annexed from the smallholder sector; smallholder farmers were not allowed to grow export crops such as tobacco, tea and sugar; and they were paid less for their produce by the estate marketing board (Conroy 2006; Chinsinga 2002).

This approach institutionalized poverty. On the one hand there were Malawians that had unlimited access to land, could grow any crops, had free market policies and access to commercial credit. On the other hand, were Malawians restricted to growing less productive crops, the prices of their produce was determined by the government and they were paid lower wages for their labour (Kennedy 1996). The natural disasters that hit Malawi in the late 1970s worsened the situation of smallholders and the same time decreased social spending. The poverty situation was worsened as Malawi adopted Structural Adjustment Programmes in 1981.

Despite the government's priorization of productive over social sectors, there were some notable improvements in social indicators. For instance 'infant mortality declined from 200 per 1,000 in 1964 to 130 and per capita daily calorie intake increased from 2,250 in 1964 to 2,400 in 1975' (AFRODAD 2007: 18; Booth et al. 2006). GDP grew by an average of 8 per cent between 1965-73 (World Bank 1975). By 1981 Malawi had raised its domestic investment from 9 per cent of GDP at independence to 25 per cent while domestic savings increased to 17 per cent (Record 2007).

The benefits of economic growth in the 1980s and 1990s did not reduce poverty. By the early 1990s, 63 per cent of the population remained under the poverty line (UN 1993). This situation underpinned the policies implemented from 1994 under the democratic leadership of Bakili Muluzi who was a former secretary general of Banda's party. There was a major shift in policy orientation towards poverty reduction. Allocations towards social sectors such as health and education received a major boost in the budget. The government introduced free primary education which increased enrolment, especially that of girls (Nthara 2003). The Poverty Alleviation Programme (PAP) designed in 1994 guided policy to be achieved through a participatory process with the poor that 
empowered them to change their livelihoods (Kennedy 1996; Chinsinga 2002). Despite being well-articulated, the PAP had little impact on actual programmes and expenditure decisions. It failed to define the target groups or stakeholders and there was no real understanding of who the poor were, what poverty was, and the specific solutions to be applied to different dimensions of poverty (Chinsinga 2002; Bloom et al. 2005).

Ellis et al. (2003) observe that by 1999, Malawi had abandoned the PAP and adopted the Malawi Poverty Reduction Strategy Paper (MPRSP), which became fully operational in 2002. This approach was built around four pillars: sustainable pro-poor economic growth; human capital development through education and health; improving the quality of life of the most vulnerable through safety nets; and good governance. A distinguishing feature of the MPRSP was its commitment to the classification of certain budget lines under the programme as Pro-poor Expenditure (PPE), these were to be protected against cuts. Despite these efforts the MPRSP failed to have its desired impact, resources were diverted to non-priority areas. In 2003 instead of the projected increase in PPE expenditure to 25.2 per cent, there was a decline of 9.2 per cent (IMF and IDA 2003; GoM 2005).

Muluzi's two terms in office have been described as the 'lost decade' since no real economic growth took place. Between 1995 and 1998 Malawi's growth rate averaged 4.6 per cent per annum; dropped to 1.4 per cent between 1998 and 2001; and was negative between 2001 and 2002. Fiscal indiscipline characterized this period with the government spending more than its revenues and grants, thereby increasing internal and external debt. Domestic debt increased from MK9.5 billion at the end of 2001 to MK54.5 billion early 2004 and interest on this debt alone accounted for 10 per cent of the national budget (Whitworth 2004 in Conroy 2006). At the time Muluzi left office in 2004 GDP per capita remained at US\$160, the same level as when he assumed office in 1994. This is a clear indication of the poor living conditions of most Malawians, especially if we account for population growth. The expectations that democracy offered to the poor and the economy in general did not materialize.

In response, the second democratic government elected in 2004 embarked on a growthoriented strategy that acknowledged the need to effectively reduce poverty. Guided by the Malawi Growth and Development Strategy (MGDS), it focuses on six priority areas: agriculture and food security; irrigation and water development; transport and communication; infrastructure development; prevention and management of nutritional disorders; HIV and AIDS (Government of Malawi 2008). Since 2006 growth has averaged 7.5 per cent, which has been supplemented by social protection policies such as the subsidy programme, cash transfers towards female/child-headed households and old age pensions. The cash transfers are still being piloted while old age pensions have yet to be implemented.

As a result of such policies, inflation has been below 10 per cent since 2007 and there has been an increase in maize production. The increase in maize production is attributed to the implementation of the subsidy programme since 2005 (Chinsinga and O'Brien 2008). Prior to implementing the social protection policy, policies towards poverty had been ad hoc, mainly short-term relief or emergency support. There have been some extensive programmes, particularly the subsidized agricultural input programme but resources were thinly spread and failed to have the desired impact on poverty. According to Tsoka and Slater (2007) the social protection policy initiative is a more long-term predictable social protection programme that helps poor households deal with risks and shocks with a more institutionalized and coordinated approach (Tsoka and Slater 2007: 7). 
These changes in government policies-particularly the emphasis on subsidies, which have been fully budgeted for in the national budget while cash transfers are still being piloted and old age pensions are yet to be implemented-raise questions as to how elites perceive poverty, its causes and solutions. Elites represent a group that is actively involved in policy-making and the literature shows that the way elites define or frame the problem of poverty has an impact on the solutions they proffer. Although, elite perceptions are not the singular explanation for understanding poverty, its causes and solutions, the political nature of poverty makes elites’ perceptions important.

\section{Elite understanding of poverty and the poor}

The fieldwork on which this paper is based was undertaken in 2008. The objectives of the study point to the importance of views expressed by elites about poverty and poor people as well as their attitudes, values, and norms. Some research has been carried out in Malawi on elite capture 1 but none has attempted to understand elite perceptions, 2 how they affect pro-poor policy and how they can possibly be changed to the benefit of poor people.

The study is interested in powerful individuals, those who are in decision-making positions and those who exercise influence over decisions that involve the implementation of pro-poor policy. Elites are defined here as the most powerful people within any political system who are able to influence or shape political and economic decisions. Hence a positional approach towards identifying the sample of elites was used. The positional approach is based on the assumption that power in society is based on resources associated with positions of authority. Therefore, holders of key positions in political, public or private institutions are identified as belonging to the elite (Hoffman-Lange 1987). The adoption of a positional approach ensured that few elites were missed in the process of sampling, making it more inclusive. The target group was individuals that hold key positions within institutions that directly influence pro-poor policy, for instance the Ministry of Economic Development and Planning, the Ministry of Finance, local government, and so on. However, it also included other ministries/departments that were indirectly involved in the planning of pro-poor policy such as the Ministry of Foreign Affairs, principal secretaries in the President's office and cabinet as well as advisors to the president. Those targeted were ministers, principal secretaries, members of parliament from the ruling party, members of parliament in opposition, heads of media organizations, heads of civil society organizations, donor agencies, and heads of parastatals.

A 100 individuals were given a questionnaire and 60 were asked for face-to-face interviews. 3 The respondents were requested to provide information on their understanding of poverty, its causes and strategies, their attitudes and value orientations including their sociodemographic information.

1 Elite capture is the assumption made in much of the literature that the obstacle to successfully implement policy, particularly pro-poor policy, lies in the kleptocratic behaviour of elites.

2 Elite perception comprise of evaluative and non-evaluative understanding of a situation. Perception refers to three things: cognition (non-evaluative understanding); norms (internalized ideas about appropriate roles and values (ideals about what might be) (Reis and Moore 2005:3).

3 Of the 100 questionnaires sent out 86 were returned and of the 60 requests for interviews, 52 were interviewed. 
In addition to the interviews, a review of official records was carried out which included proceedings of parliament's budget sessions between 1965 and 2007, newspaper articles between 1996 and 2008, and presidential speeches sourced from the Malawi Broadcasting Corporation covering the three main presidents since 1964 (Dr Banda (1964-91); Dr Muluzi (1994-2004); and Dr Wa Mutharika (2004-08)). The review concentrated on understanding how the issues concerning poverty and the poor were discussed, how pro-poor policy was analysed and tried to understand whether specific events impacted on elite support for pro poor policy. Observations were integrated into the study to capture what elites actually do or say rather than what they say they do and it provided additional information or insight into elite perceptions, level of collective action, and coordination. The following section presents elite perceptions of poverty and the poor and analyses the extent to which mutual dependencies between elites and the poor impact policy support.

\subsection{Extreme poverty but a visible happy rural poor and an invisible suffering urban poor}

Malawian elites are well aware of the problem of poverty and consider it to be the most important issue facing Malawi. A majority of the respondents in the semi-structured interviews opened the discussion with the fact that poverty is real, severe, rampant and is a problem for Malawi's development. They were not under any illusions as to the incidence, severity, and location of poverty. When asked to indicate what the main obstacles to democracy were, social issues were ranked the highest (Table 1). When the question referred to national problems elites still ranked social issues as the main problems. Table 2 shows that poverty was the top choice for elites followed by education and health. More than half of the respondents selected other social issues as well as unemployment and income distribution.

It is not surprising that elite estimates of the level of poverty are higher than the official statistics. Table 3 shows that contrary to the official view that poverty is declining in Malawi some elites indicated that with the exception of a few elites, the whole nation is poor. Elites within the civil service indicated that to be politically correct they would peg poverty at a little over 50 per cent, but when they felt in earnest that it was over 65 per cent. As one influential high-ranking government official stated that 'to be realistic

Table 1: Obstacles to democracy

\begin{tabular}{lccc}
\hline & Yes & No & Total \\
\hline Low educational levels & 64 & 22 & 86 \\
High levels of poverty & 61 & 25 & 86 \\
Lack of party tradition & 32 & 54 & 86 \\
Incompetence of those in power & 11 & 75 & 86 \\
Selfishness of elites & 36 & 50 & 86 \\
Political clientelism & 24 & 62 & 86 \\
Power centralized in the Executive & 32 & 54 & 86 \\
High inflation rate & 0 & 86 & 86 \\
\hline
\end{tabular}

Source: see text. 
70 per cent of Malawians are poor'. Elites noted that the data being used to tabulate the official statistics was collected several years back and does not represent poverty in 2008. They argued that people's needs have changed and the present estimation of poverty is based on an international understanding which does not reflect the local understanding of poverty. Elites' high estimation of the extent of poverty suggests two things: one, that there is interdependence between elites and the poor such that elites are not shielded from the realities of poverty. Second, this can aid attempts to introduce policy that will actually reduce poverty and ensure the political will to implement these policies. According to Reis and Moore (2005) the use of the poverty line in the UK, by Charles Booth (1889) was able to inspire support from elites towards the poor which has not occurred in Malawi. The mere presentation of poverty as 'those living below a dollar a day’ has worked to desensitize Malawian elites.

Table 2: Malawi's most important problems

\begin{tabular}{lccc}
\hline & Yes & No & Total \\
\hline Inflation & 26 & 60 & 86 \\
Education and health & 64 & 22 & 86 \\
Poverty & 77 & 9 & 86 \\
Governability & 40 & 46 & 86 \\
Income distribution & 47 & 39 & 86 \\
Political patronage/clientelism & 44 & 42 & 86 \\
Corruption & 62 & 24 & 86 \\
Behaviour of the elites & 34 & 52 & 86 \\
Moral crisis & 28 & 58 & 86 \\
Unemployment & 53 & 33 & 86 \\
Foreign dependency & 45 & 41 & 86 \\
Other social issues & 58 & 28 & 86 \\
Other political issues & 31 & 55 & 86 \\
Other economic issues & 26 & 60 & 86 \\
\hline Source: see text. & & &
\end{tabular}

Table 3: Elite estimate of poverty

\begin{tabular}{lc}
\hline Elite estimation of the proportion of the poor & Elite \\
& $\mathrm{n} \%$ \\
\hline $70-100 \%$ & 2242.3 \\
$50-69 \%$ & 2242.3 \\
$40-49 \%$ & 59.6 \\
Missing value & 35.8 \\
Total interviewed & 52100 \\
\hline
\end{tabular}

Source: see text. 
This could be because the poverty line in Malawi is calculated based on food expenditures in relation to individual food requirements and critical non-food consumption (IHS 2005). Hence, elite's description of poverty is in terms of lack of access to basic needs, mostly food, shelter, clothes, and foot wear. Lack of access to social services such as health, water, and education were seen as secondary to basic needs. Poverty was hardly discussed in terms of the socioeconomic relations that keep people poor, such as access to land, empowerment or participation in decision-making. Despite their high estimations of poverty, elites will not likely be shocked by poverty in Malawi as they see it as a result of the poor's inability to do what is necessary to reduce their poverty. The reason that the poor face hunger is because they do not work hard and fail to be innovative due to illiteracy.

This view of the poor is evident in elite categories of the poor which are also similar to those prevalent in the international discourse on poverty. The poor were ranked as either ultra poor, i.e. those who lack all the basic necessities of life, have no labour, and survive on a day-to-day basis. The second group was that of poor people who have the energy and ability but lack the economic or social opportunities to live a decent life. The last group is that which is considered better off in relation to the rest of the community. This group can afford at least one meal a day, some form of clothing, and can access markets. However, elites pointed out that in comparison to international standards of poverty, all three groups still fall below the poverty line. These three categories divide the active and the inactive poor, which determined the policies to be targeted towards each group. Though, not in support of welfare transfers, the ultra poor were those that could be targeted by cash transfers as they need help all the time. The elderly, children, and the disabled were identified as belonging to this group. The last two groups were seen as qualifying for subsidy or cash for work programmes as they have energy and ability.

An interesting contrast emerged on the location of the poor between the rural and urban areas. Elites argued that although there are more poor people in the rural areas, the pain of poverty is felt in the urban areas. There was an idealized view of the rural poor, who were described as 'comfortably poor' and better able to survive because of access to land. The rural poor were seen as having a good support system because they live among kin who can easily share with them. In contrast, the urban poor have no access to the family support system because those whom they interact with are strangers also trying to survive. However, it is believed that the urban poor are surrounded by resources and opportunities and all they need to do is work hard. By default if one is poor in urban areas then he is deemed lazy. As one respondent noted 'in urban areas the poor have opportunities and if they had a little imagination they should not be poor'. Elites noted that social policy has mainly targeted rural poor because poverty is more visible. Not only in terms of numbers (85 per cent of Malawians live in rural areas) but also in the outlook of the poor, who are scantily dressed and look hungry and dirty. The urban poor become invisible because they are at the edge of the suburbs and they may have better clothing to put on.

Elite responses indicated that urban poverty has not been seriously considered by the elite and that there is an idealized view of the rural poor. There was a tendency to forget the poverty in their own midst and to assume that social ties in the rural areas are still strong. Some elites argued that just like in urban areas, in the rural areas it is survival of the fittest.

These days you hardly see the stratification that used to be there in the rural areas. Because in the past you could go into the rural areas and 
immediately notice that there are some people who are slightly better off and those that are not doing so well. But now a common response from the people out there is that we are all poor, there is no difference between the rural and urban poverty, especially if poverty is in those traditional settlement areas (interview with academic, May 2008).

Malawi is considered to be a highly unequal country, at times likened to levels of inequality in Brazil and considered the highest in Africa (Durevall 2002). Inequality in Malawi had been steadily rising from 1968 at a Gini index of 0.48 to 0.62 in 1995 and 0.88 in 1998. Respondents held similar views that there is a wide gap between the rich and the poor in Malawi in terms of income, gender, access to productive resources such as land and access to social services such as education. Structural explanations that emphasize power differentials in society were used by elites to explain gender and access to basic services inequality. For instance stereotypes in Malawi's tradition and upbringing were seen to worsen gender inequality as women are posited as inferior to men. Interestingly, a more individualistic approach was applied when discussing income inequality. Elites argue that there is equality of opportunities and the poor make bad choices. One minister pointed out that income inequality is only beginning to show because the rural poor spend their time working on other people's land rather than in their own gardens; 'The rural poor prefer to make money for the day, therefore the rich become richer and the poor poorer'.

Elites felt that inequality does not lead to any form of unrest because poverty has been a constant companion for Malawians. 'It is like a tradition, to be poor and not to have access to basic needs is the order of the day, it is normal, it is the way things are. Poor people are resigned to their fate' (interview with civil society leader, April 2008). On the other hand, the poor cannot organize for mass action because as Malawians we organize vertically instead of horizontally and any mass action dies a natural death without achieving its intended impact. Poor people consider relationships with MPs or those in authority within the civil service as more important and they will conspire with those in authority, hence report any plans for mass action. The poor are seen as letting 'sleeping dogs lie' to preserve communal life where the poor and elites are dependent on each other.

\subsection{The main causes of poverty}

Answers about the causes of poverty converged on the low levels of education of the Malawian people, which has resulted in high illiteracy rates. Poverty reduction policies were seen as meaningless if the recipients are uneducated. Education is what determines the extent to which the poor will use the resources made available to them and their attitude towards development. Education referred not only to higher education but also to entrepreneurial training which would enable the poor to develop innovative ideas to use the available resources. 'Education is the key as it impacts on the attitudes of the poor and if people are educated, then they have a positive attitude towards development' (statement by top government official).

Elite diverged on the impact that behaviour and attitudes of the poor have on poverty levels in Malawi. Some stressed that the position of the poor was not due to a fault of their own. This group stressed that many of the poor are hard working but that they have not been empowered through training or with resources, both land and financial, to make their lives better. Others argued that the poor are unproductive and lazy leaving a 
situation where an unproductive 70 per cent of the population depends on the productive 30 per cent.

Of the respondents that mentioned laziness and lack of hard work directly, they related these behaviours to the poor's passive mentality, culture of dependence, their view of poverty fate, and generally holding values negative for development. Other frequent answers included lack of minerals like diamonds and gold that can spur growth and most importantly Malawi's dependency on agriculture. Respondents noted that Malawi has been heavily dependent on agriculture for decades, but still uses primitive methods of farming which results in poor yields. 'We are still using a hoe, we have not mechanized and we have huge resources of water but we have not gone into massive irrigation schemes. We still wait for the rain and hence only plant once a year' (member of parliament). This view of the poor as passive and dependent highlights the relationship that elites have with the poor and also explains in part the lack of fear elites have from the presence of poverty and the poor.

In addition, poor policy implementation, lack of political will, corruption, and bad governance were considered to also be causes of poverty in Malawi. Respondents suggested that many policies were designed to please donors rather than the Malawian people, making them a failure from the planning stage. Others noted that the donor argument was just an excuse to divert attention from the source of the problem-the elites. They argued that the amount that Malawi receives from donors is not proportionate to the development that one sees on the ground. 'Donors are not responsible for our poverty; the government has implemented structural adjustment programmes, poverty alleviation policy, MPRSP, MDGs, and the Malawi growth development strategy with no real impact on poverty. Instead of developing policy based on these previous policies, elites are requesting to travel to Brazil and South Africa, to study their social protection policy' (interview with prominent leader, parliament, April 2008).

\subsection{Strong ties, minimal observable threat}

Elites distinguished their relationship with the poor between personal and professional links. The personal links were through extended family, the poor that work in their households or their farms and those that beg in the cities. Through these links elites are expected to provide financial resources through wages, paying schools fees for relatives' children especially those that have lost their parents through HIV/AIDS, and those seeking alms on the streets. For members of parliament, this involved paying fees for children in the constituency, paying for funeral costs, and providing financial assistance towards development projects such as the construction of boreholes. Professionally, the links with the poor are there as as their representatives in parliament, or through influence on pro-poor policy from those working in the civil service and the provision of goods and services, especially from civil society. There was consensus that elites have strong connections with the poor because each one has links with their home villages and has experienced poverty at one point in their lives.

Despite strong views about the interdependence between elites and the poor, elites did not feel threatened by the growing presence of the poor in Malawi. They explained that the poor are too concerned with survival to cause civil unrest, or be involved in criminal activities and are resigned to their fate that they fail to act in any meaningful way. Those involved in crime are not the poorest of the poor but lazy people who want to get rich 
quickly. 'The poor simply do no have the energy to be involved in crime because they would not be able to run away' (interview with civil society leader, April 2008). The factors that increase crime are the high unemployment rates and the breakdown of the social security system itself, not poverty. Those elites that identified a link between poverty and crime noted that police reports indicate that as inflation increases so does crime. However, they tended to compare Malawi to neighbouring countries pointing out that Malawi's crime does not have the same impact as in other countries.

However, an analysis of parliamentary proceedings indicates that elites are concerned with growing crime in Malawi. During discussions on a bill to tighten judicial procedures for dealing with criminals, elites expressed concern that those who are better off lived in fear of criminals as they were their main targets. They noted that growing crime deterred investment in Malawi and has an effect on the county's growth. It was argued that crime was a result of lack of economic empowerment of the Malawian people and lack of responsibility on the part of the poor towards development (National Assembly debates, 34th session, 27 June 2000).

Although elites did not directly link poverty to crime, they indicated a strong link between poverty and disease. It was argued that poor people are more prone to disease because of poor nutrition and poor sanitation. Elites felt that they are highly insulated from diseases and crime because they have security, they are able to travel abroad for education and medical care. 'I cannot take my family to a hospital that I know is below standards but that does not mean I am doing nothing to change the situation' (interview with minister, May 2008). Other elites felt that the evidence from HIV/AIDS, which is attacking both rich and poor, is an indication that elites are not insulated from diseases that the poor have. Elites noted that many girls from poor households flock into the cities in search of money and they end up in prostitution. Their targets are the elites and that can be how elites are getting HIV/AIDS.

Table 4: Coping strategies of the vulnerable segments of society

\begin{tabular}{lccc}
\hline Strategy & Rural & Urban & National \\
\hline Begging & 4.8 & 1.6 & 3.2 \\
Assistance from relatives & 67.6 & 45.3 & 56.5 \\
Assistance from friends & 40.7 & 50.9 & 45.8 \\
Charitable organizations & 1.4 & 3.0 & 2.2 \\
Street vending & 5.1 & 8.2 & 6.6 \\
Past savings & 13.2 & 28.6 & 20.8 \\
Working for food & 17.3 & 2.0 & 9.7 \\
Prostitution & 0.9 & 0.9 & 0.9 \\
Selling used clothes & 1.2 & 4.5 & 2.8 \\
Buying second hand clothes & 13.9 & 17.5 & 15.7 \\
Sending kids to relatives & 3.9 & 1.8 & 2.8 \\
Other & 57.6 & 2.7 & 40.4 \\
\hline Source: Chilowa et al. (2000) cited in Chinsinga
\end{tabular}

Source: Chilowa et al. (2000) cited in Chinsinga (2002: 31). 
A recurring element in the study was that social networks that connect elites and the poor have a direct impact on elite welfare. This observation is consistent with a study carried out by Chilowa et al. (2000) that identified assistance from relatives as the poor's major coping strategy (see Table 4). Political elites pointed out that apart from extended family; they have had to cater to the needs of their constituents. They were weary of the demands pressed on them that they indicated that they have called on civil society to educate Malawians on the role of a member of parliament. It was the custom to find constituents at the offices of several ministers I was interviewing asking for schools fees, transport to return to the constituency, employment, and so on. Elites noted that since government provided ambulances to the rural areas, calls on members of parliament to pick up sick people to transport them to the hospital, even the dead to the mortuary, have reduced. Bureaucratic and civil society elites expressed concern over their failure to personally develop or lead a comfortable lifestyle due to pressure from extended families. There was consensus that social networks are breaking down and that charitable works should not rest solely on elites.

\subsection{Poverty reduction as a priority —not beyond the budget}

A look at Malawi's budget indicates that priority has been given to the reduction of poverty and at least 70 per cent of the budget goes towards poverty-related expenditures. Elites agreed that this suggests that poverty is a priority but they argued that few have had have had much impact on poverty. Elites were concerned that Malawi cannot develop with the present levels of poverty but argued that poverty reduction should not be tackled in isolation from economic growth policies. Elites noted that to effectively deal with poverty, Malawi should stop developing multiple policies and begin to develop consistent, sustainable and coherent policies. The pro-poor policies developed need to be comprehensive enough to ensure that there is no constant shifting of position or direction.

Elites are aware that poverty exists but they point out that this does not translate into poverty reduction. 'We need to find ways of pricking the conscious of all elites about poverty. There is no evidence to show that we are putting a premium on poverty reduction. Our government and elites in general are not doing enough to reduce poverty' (Speaker of Parliament). Elites differentiated the priority given towards poverty reduction between the Banda, Muluzi, and Mutharika regime. They felt that under Banda things worked well and there is need to study the time before Malawi started receiving donor funds as this was the most economically successful time. The Muluzi regime is considered to have displayed less interest in reducing poverty despite being its main policy and receiving large amounts of donor funds towards alleviation. Although there was a belief that this was improving under Mutharika, elites noted that there is need for more champions of poverty reduction.

Some elites argued that failure to prioritize poverty was because elites benefit from the existence of poverty. The poor provide access for elites to cheap labour, votes, and employment. 'Elites are benefiting from working within the HIV/AIDS industry and would not want to see poverty reduced. Even our donors, if there was no poverty, they would be out of a job' (interview with civil society leader, April 2008). The fact that the Malawian population is uneducated, fear authority, and is not confident, is a source of gains for the elites. One respondent noted that one often hears comments from opposition parties that 'if only there was hunger or the roads were in bad shape, we could win the elections in 2009'. Other elites disagreed with this notion arguing that 
there is no one who would want poverty to remain at present levels, arguing that it would actually be better if the poor were better off. Most elites run businesses and rely on the poor to buy their products and if there were less poor people, government would reduce its expenditure towards them to more productive areas.

\subsection{The poor should help themselves out of poverty}

Despite consensus that there should be no distinction between deserving and undeserving poor, elites tended to offer policies that favoured the active poor. Policies such as public works, subsidies, microfinance were favoured over cash transfers or old age pensions (see Table 5). The first six highlighted policy choices in Table 5 illustrate these preferences and also show elites' choice of education and primary health care as favourable. These two policies are considered as enabling the poor to be more active, for instance education will help the poor to be innovative and spot opportunities. On the other hand, primary health care will ensure that people are healthy to contribute actively to development. It was common for elites to argue that sometimes no matter what government does to reduce poverty the poor do not work hard. Therefore, it is important to choose between cash for work programmes, cash transfers, pensions or food for work

Table 5: Elite policy preferences

\begin{tabular}{|c|c|c|c|c|c|}
\hline Policy & $\begin{array}{l}\text { Viable and } \\
\text { desirable }\end{array}$ & $\begin{array}{l}\text { Desirable but } \\
\text { not viable }\end{array}$ & $\begin{array}{c}\text { Viable but } \\
\text { not } \\
\text { desirable }\end{array}$ & $\begin{array}{c}\text { Neither } \\
\text { viable or } \\
\text { desirable }\end{array}$ & Total \\
\hline Micro finance & 66 & 9 & 4 & 9 & 86 \\
\hline Public works programme & 61 & 12 & 9 & 4 & 86 \\
\hline $\begin{array}{l}\text { Free and universal } \\
\text { primary education }\end{array}$ & 60 & 23 & 1 & 2 & 86 \\
\hline Fertilizer subsidies & 51 & 28 & 3 & 4 & 86 \\
\hline $\begin{array}{l}\text { Free and universal } \\
\text { primary health services }\end{array}$ & 51 & 29 & 2 & 4 & 86 \\
\hline $\begin{array}{l}\text { National safety nets } \\
\text { programme }\end{array}$ & 41 & 23 & 13 & 9 & 86 \\
\hline Old age pensions & 37 & 31 & 6 & 12 & 86 \\
\hline $\begin{array}{l}\text { Cash transfers/ direct } \\
\text { welfare transfers }\end{array}$ & 27 & 29 & 12 & 18 & 86 \\
\hline $\begin{array}{l}\text { Popular housing } \\
\text { programmes }\end{array}$ & 26 & 43 & 2 & 15 & 86 \\
\hline Child benefits & 25 & 35 & 4 & 44 & 86 \\
\hline Free University education & 18 & 44 & 4 & 20 & 86 \\
\hline $\begin{array}{l}\text { Minimum income for } \\
\text { different age groups }\end{array}$ & 18 & 30 & 6 & 32 & 86 \\
\hline $\begin{array}{l}\text { Food distribution } \\
\text { programmes }\end{array}$ & 17 & 34 & 14 & 21 & 86 \\
\hline Unemployment insurance & 13 & 33 & 11 & 29 & 86 \\
\hline
\end{tabular}

Source: see text. 
programmes. Elites indicated that cash transfers were handouts, which create dependency and targets an unproductive sector. They were concerned that it would be difficult to raise taxes to accommodate cash transfers or the social protection policy in general. 'Yes I am my brother's keeper but the poor also have a responsibility towards poverty reduction. I am not saying all poor people are lazy' (speaker of parliament).

Semi-structured interviews and questionnaires both found that elites saw education as the main avenue out of poverty. Education was viewed in terms of awareness of responsibilities, ability to take advantage of markets and exploit available resources. There were strong sentiments that there is need to invest in the manufacturing sector and continue to improve agriculture through diversification.

\subsection{Faith in government capability to steer pro-poor policy}

Government was named as the institution that should take full responsibility towards poverty reduction. Government was seen as better coordinated than the private sector and also responsible for the delivery of goods and services. However, elites noted that to succeed in reducing poverty, coordination was important among the different categories of elites, from those in power, opposition, civil servants, civil society, donor community, the media, and the poor themselves. Coordination should be from planning through to implementation and poverty reduction should become the goal of all Malawians. They should be united and develop a sense of nationalism.

The media was seen as very important for changing the discourse within the Malawian society which is seen as 'obsessed' with issues of personality politics compared to development issues. The media was seen as a tool for changing the mindsets of the poor towards work and development. There was agreement that Malawians needed to move away from Banda's four cornerstones of unity, obedience, loyalty, and discipline which still dictate their behaviour.

However, elites were concerned that the high corruption rate within the civil service goes unnoticed and that there is need to strengthen accountability systems within government. The anti-corruption bureau, National Audit Office, Public Procurement, and Public Prosecutions were identified as the institutions that needed immediate restructuring to be more effective so that real change can take place.

Elites felt that civil society in Malawi does not provide an alternative voice to government and were concerned that they were driven by donor interests and not the interests of the poor. They noted that civil society was not transparent in the way their funds are spent nor accountable to the people on whose behalf they source funding.

\section{Conclusion}

The argument that elites need to develop a social consciousness in order to form and implement pro-poor policy effectively suggests a development of ideological and pragmatic concerns (Bird 2007). Elites in Malawi are not threatened by crime or by the fear that the poor might start a rebellion. This could be because elites are provided with security through their employment as ministers, principal secretaries, heads of civil society organizations or parastatals and others invest in private security. While they see a correlation between disease and poverty, they do not think that it presents a threat to their own lives. 
Elites in Malawi clearly support education as the best mechanism for reducing poverty. They believe that this will facilitate development in that the poor are able to take advantage of policy or resources provided as well as start to demand from government and effectively participate in development. In similar studies in South Africa, Brazil, Bangladesh, and Uganda, education was advocated because through education everyone can get richer without the need for redistribution (Bird 2007). Elites in Malawi also perceive education as an enabler to take action to change one's fate, in this case poverty.

The evidence indicates that elites refused to overtly adopt individualistic theories that apportion blame for poverty towards the poor themselves. They argued that the poor were not necessarily lazy, but the elites were concerned that the poor's fatalistic attitudes lead them to accept their life as normal. Therefore, the poor are not inclined to work hard because they are resigned to poverty as a way of life. They feel marginalized, distant from the government and live for the present, which is self-perpetuating and is passed on to future generations. Inadvertently, these arguments indicate that elites place the blame for the existence of poverty in Malawi on the poor. The poor are therefore considered to hold behaviours, values and deviant attitudes different from the rest of society which makes them unable or unwilling to take advantage of emergent opportunities (Moore 2001 in Bird 2007). It is these innate characteristics of poor people that influence policies that target the deserving and undeserving poor.

The impact of social networks on the welfare of elites highlights the coping strategies used by the poor to survive in the midst of poor policy implementation or political and environmental conditions. These strategies have been used in Malawi since the introduction of a dual policy which created a demarcation between the haves and havenots. It became the norm that the poor relied on the rich in society to survive and this has continued to the present. In the absence of government interventions on social policy the poor resorted to seeking alternative means of survival (see Table 4).

A lack of access to health facilities has led the poor to seek traditional medicine and treatment; lack of adequate water facilities has forced households to revert to unsafe and unclean sources; and the dwindling economic activities in the rural areas has led to urbanization. This has resulted in slums where many of the social amenities such as water, sanitation, and electricity are unavailable. In addition to lack of employment, this situation has made the lives of the poor worse (Chilowa et al. 2000 cited in Chinsinga 2002: 31). Other studies (Chirwa and Chilowa 1997; Pearce et al. 1996) have identified similar coping strategies, emphasizing the reliance on social networks of friends or the extended family. However, with the influence of patron-client relations Lwanda (1996 cited in Gilman 2002) argues that the poor's preoccupation with survival has led to more individualistic solutions rather than mass movement for change. The strategy of the poor has been to do what they can; through voting, belonging to a party, attending meetings and dancing at political rallies, to increase their chances of meeting their basic needs.

These vertical relationships that the poor have with the elites are likely to be the source of influence to act towards poverty reduction, especially if they are associated with personal safety and economic security. Elites are well aware of the impact crime, disease and the possibility of uprisings has on their welfare. However, elites have failed to fully connect these to the existence of poverty and therefore develop a consciousness that makes them react more responsibly in supporting pro-poor policy.

Malawian elites are clearly concerned about the levels of poverty and feel that solutions to reduce poverty exist. The main solutions advocated towards poverty reduction have 
targeted the productive or deserving poor with policies such as education and subsidies. The cases of UK and USA welfare systems point to the importance of the formation of interdependence between elites and the poor that has an impact on their welfare through crime, disease, and civil unrest. This is the main area in which the Malawi elite social consciousness is not fully developed. Elites do not fear the negative consequences of poverty and inequality and elites seem more concerned about the impact social networks such as family have on their own welfare. There was effort at collective solutions through passing of tougher laws to deal with criminals, but elites still sought individualistic solutions, such as personal security.

\section{Reference}

Action Aid (2006). 'Climate Change and Smallholder Farmers in Malawi'. Available at: www.actionaid.org.uk/doc_lib/malawi_climate_change_report.pdf

AFRODAD (2007). 'The Impact of Economic Reform Programmes on Social Services: The Case of Malawi'. Available at: www.afrodad.org (accessed 13 January 2009).

Berthoud, R. (1981). Poverty and the Development of Anti-Poverty Policy in the UK. London: Heinemann Educational Books.

Bird, K. (2007). 'Identifying and Communicating Pro-poor Policy Messages to Policy Audiences: The Case of Chronic Poverty in Uganda'. Q-Squared Working Paper 43. Toronto: Centre for International Studies, University of Toronto.

Bloom, G., W. Chilowa, E. Chirwa, H. Lucas, P. Mvula, A. Schou, and M. Tsoka (2005). 'Poverty Reduction during Democratic Transition: The Malawi Social Action Fund'. Research Report 56. Brighton: IDS.

Booth, D., D. Cammack, J. Harrigan, E. Kanyongolo, M. Mataure, and N. Ngwire (2006). 'Drivers of Change and Development in Malawi'. Working Paper 261. London: ODI.

Cammack, D., F. Golooba-Mutebi, F. Kanyongolo, and T. O’Neil (2007). 'Neopatrimonial Politics, Decentralisation and Local Government: Uganda and Malawi in 2006'. Working Paper 2. London: ODI.

Cammack, D. (2006). 'Malawi: The Politics of Hunger'. ODI Opinion 69. London: ODI.

Cammack, D. (2004). 'Poorly Performing Countries: Malawi, 1980-2002'. ODI Background Paper 3 for the ODI Study on Poorly Performing Countries. London: ODI.

Chabal, P. (2002). 'The Quest for Good Government and Development in Africa: Is NEPAD the Answer?'. International Affairs, 78 (3): 446-62.

Chinsinga, B. (2002). 'The Politics of Poverty Alleviation in Malawi: A Critical Review. In H. Englund (ed.), A Democracy of Chameleons: Politics and Culture in the New Malawi. Blantyre: Christian Literature Association in Malawi.

Chinsinga, B., and A. O’Brien (2008). 'Planting Ideas: How Agricultural Subsidies are Working in Malawi’. London: African Research Institute. 
Chirwa, E. W., and W. Chilowa (1997). 'The Impact of Structural Adjustment Programmes on Social and Human Development in Malawi'. Bwalo, Forum for Social Development, 1. Zomba: Centre for Social Research.

Chilowa, W., J. Milner, B. Chinsinga, and R. Mangani (2000). 'Social Policy in the Context of Economic Reforms: A Benchmark Survey Report’. Harare: SARIPS.

Conroy, A. (2006). 'The History of Development and Crisis in Malawi'. In A. Conroy, M. Blackie, A. Whiteside, J. Malewezi, and J. Sachs (eds), Poverty, Aids and Hunger: Breaking the Poverty Trap in Malawi. New York: Palgrave Macmillan.

De Swaan, A. (1988). In Care of the State: Health Care, Education, and Welfare in Europe and the USA in the Modern Era. New York: Oxford University Press.

Durevall, D. (2002). 'Malawi: Economic Growth, Public Sector Reform and Poverty'. Country Economic Report. Stockholm: SIDA.

Diamond, L. (2003). 'Moving Up Out of Poverty: What Does Democracy Have to Do With It?' Paper prepared for the World Bank Workshop 'Moving out of Poverty: Growth and Freedom from the Bottom Up', Washington, DC: World Bank.

Ellis, F., M. Kutengule and A. Nyasulu (2003). 'Livelihoods and Rural Poverty in Malawi’. World Development, 31 (9): 1495-510.

Government of Malawi (2005). 'Malawi Poverty Reduction Strategy: Annual Progress Report - 2003/2004'. Lilongwe: Ministry of Economic Planning. Available at: http://siteresources.worldbank.org/INTPRS1/Resources/Malawi_APR(Feb-2005).pdf

Government of Malawi (2008). 'Malawi Growth and Development Strategy Annual Status Report’. Lilongwe: Ministry of Economic Planning.

Hickey, S. (2005). 'The Politics of Staying Poor: Exploring the Political Space for Poverty Reduction in Uganda’. World Development, 33 (6): 995-1009.

Hickey, S., and S. Bracking (2005). 'Exploring the Politics of Chronic Poverty: From Presentation to a Politics of Justice?’. World Development, 33 (6): 851-65.

Himmelfarb, G. (1991). Poverty and Compassion: The Moral Imaginational of the Late Victorians. New York: Knopf.

Hoffman-Lange, U. (1987). 'Surveying National Elites in the Federal Republic of Germany'. In G. Moyser and M. Wagstaffe (eds), Research Methods for Elite Studies. London: Allen and Unwin.

Hossain, N. (2005). 'Productivity and Virtue: Elite Categories of the Poor in Bangladesh’. World Development, 33 (6): 965-77.

IHS (2005). 'Malawi Second Integrated Household Survey'. Available at: http://siteresources.worldbank.org/INTLSMS/Resources/33589861181743055198/3877319-1181928149600/IHS2_Basic_Information2.pdf

IMF and IDA (2003). 'Malawi Poverty Reduction Strategy Paper - Progress Report: Joint Staff Assessment' Available at: http://poverty2.forumone.com/files/Malawi_PRSP_APR_JSA.pdf

Kennedy, W. K. (1996). 'Reaching the Unreached: Challenges for the 21st Century' Paper presented at the 22nd WEDC Conference, New Delhi, India. 
Lister, R. (2004). Poverty. Cambridge, UK: Polity Press.

Lwanda, J. L. C. (1996). Promises, Power Politics and Poverty: Democratic Transition in Malawi. Glasgow: Dudu Nsomba Publications.

Pearce, J., A. Ngwire, and G. Chimsey (1996). Living on the Edge - A Study of the Rural Food Economy in the Mchinji and Salima Districts of Malawi'. London: Save the Children UK.

Moore, K. (2001). 'Frameworks for Understanding the Intergenerational Transmission of Poverty and Well-being in Developing Countries'. CPRC Working Paper 8. Birmingham: University of Birmingham.

Narayan , D, R. Chambers, M. Kaul Shah, and P. Petesch (1999). 'Global Synthesis: Consultations with the Poor'. Paper prepared for the Global Synthesis Workshop: Consultations with the Poor. World Bank, Washington, DC. Available at: http://www1.worldbank.org/prem/poverty/voices/synthes.pdf

Narayan, D., R. Patel, K. Schafft, A. Rademacher, and S. Koch-Schulte (2000a). Voices of the Poor: Can Anyone Hear Us?. New York: Oxford University Press for the World Bank.

Narayan, D., R. Chambers, M. Kaul Shah and P. Petesch (2000b). Voices of the Poor: Crying Out for Change. New York, NY: Oxford University Press for the World Bank.

Narayan, D. and P. Petesch (2002). Voices of the Poor: From Many Lands. New York, NY: Oxford University Press for the World Bank.

National Statistical Office (NSO) (2005). 'Integrated Household Survey 2004-2000'. Volume I: Household Socio-Economic Character. Zomba. NSO.

Nthara, K. (2003). 'Malawi’s Economic Development Since 1994: Implications for Democratisation in From Freedom to Empowerment'. In B. Immink, S. Lembani, M. Ott, and C. Peters-Berries (eds), Ten Years of Democratisation in Malawi. Balaka: Montfort Media.

O’Neil, T. (2007). 'Neopatrimonialism and Public Sector Performance and Reform'. ABIA Background Note 1. London: ODI.

Pryor, F. (1990). The Political Economy of Poverty, Equity and Growth: Malawi and Madagascar. Oxford: Oxford University Press.

Rakner, L., L. Mukubvu, N. Ngwire, and K. Smiddy (2004). 'Budget as Theatre - The Formal and Informal Institutional Makings of the Budget Process in Malawi'. Oslo: Chr. Michelsen Institute. Available at: cmi.no/publications/file/?1928=the-budget-astheatre-the-formal-and-informal

Record, R. (2007). 'From Policy to Practice: Changing Government Attitudes towards the Private Sector'. Journal of International Development, 19: 806-16.

Reis, E., and M. Moore (2005). Elite Perceptions of Poverty and Inequality. London: Zed Books.

Riddell, R. (1999). 'The End of Foreign Aid to Africa? Concerns about Donor Policies'. African Affairs, 98 (392): 309-35. 
Robinson, J. (2003). 'Politician-Proof Policy'. Background Paper to the 2004 World Development Report.

Selee, A. (2005). 'Perceptions and Misconceptions in US-Mexico Relations'. The Woodrow Wilson Center and Letras Libres. Available at: http://www.wilsoncenter.org/topics/pubs/Mexico_Perceptions_new.pdf

Squires, P. (1990). ‘Anti-social Policy’. In R. Lister (ed), Poverty. Cambridge, UK: Polity Press.

Tsoka, M., and R. Slater (2007). 'Malawi Social Protection Status Report'. Working Paper 40027. Washington, DC: World Bank.

Toye, J. (1999). 'Nationalising the Anti-poverty Agenda'. IDS Bulletin, 30 (2): 6-12.

USAID (2002). 'Urban Profile: Malawi'. Available at: www.makingcitieswork.org/files/pdf/africa/Malawi.pdf

Whitworth, A. (2004). 'Malawi's Fiscal Crisis: A donor Perspective’. Paper presented to Members of Parliament, Civil Society, and the General Public.

Witteveen, A., E. Ludi, and G. Felber (2008). 'Perceptions of Poverty’. Briefing Note 2. Available at: www.poverty-wellbeing.net.

World Bank (1975). 'Recent Economic Development and Prospects of Malawi', Country Programs Department 11: Eastern Africa Region Report 560. Washington DC: World Bank.

World Bank (2000/2001). 'World Development Report'. Washington DC: World Bank. Available at: http://go.worldbank.org/7KWQQ1WVT0 